\title{
Maskevarri Ráhppát in Finnmark, northern Norway - is it an earthquake-induced landform complex?
}

\author{
R. Sutinen, I. Aro, P. Närhi, M. Piekkari, and M. Middleton \\ Geological Survey of Finland, P. O. Box 77, 96101 Rovaniemi, Finland \\ Correspondence to: R. Sutinen (raimo.sutinen@gtk.fi) \\ Received: 30 November 2013 - Published in Solid Earth Discuss.: 22 January 2014 \\ Revised: 21 May 2014 - Accepted: 22 May 2014 - Published: 21 July 2014
}

\begin{abstract}
The Sami word ráhppát means rough bouldery/stony terrain with sharp-relief topography in Finnmark, northern Norway. Ráhppát is a common name in the region of the Younger Dryas landforms, yet the origin of ráhppát has remained obscure. The timing of the Younger Dryas is concomitant with the maximum neotectonic fault instability in Fennoscandia. Hence, earthquake activity may have been one of the contributing factors for the Younger Dryas morphologies. Ráhppát on the Maskevarri fell, classified as a part of Troms $\varnothing$-Lyngen sub-stage of the Younger Dryas, was studied by means of geomorphology and measurements of electrical-sedimentary anisotropy. Ráhppát was found to be built up of an anastomosing network of stony eskerlike ridges and mounds bordered with arch-shaped and sinusoidal ridges. These bordering ridges exhibit sedimentary (azimuthal soil electrical conductivity) anisotropy parallelto-ridge trends and were interconnected to meltwater gullies suggesting generation through short-lived conduit infills. We did not find electrical-sedimentary evidence to support the concept of englacial thrusting and/or compression, often described for Younger Dryas moraines. Maskevarri Ráhppát is typified by $\sim 500$ ponds and small lakes on three different elevations descending in an up-ice direction. These may have generated through late glacial earthquake(s) also contributing to subglacial deformation of Maskevarri Ráhppát.
\end{abstract}

\section{Introduction}

In maps and orthophotos (Norkart Geoservice AS and Geovekst), the name ráhppát is often found given to landforms (classified as moraines or marginal moraines) constituting the Gaissa and the main (Troms $\varnothing$-Lyngen) sub-stages of the Dryas events (Sollid et al., 1973; Sollid and Sørbel, 1988; Olsen et al., 1996; sub-stage positions in Fig. 1). After the maximum extent of the Fennoscandian Ice Sheet (FIS) at about $25 \mathrm{kyr}$ BP (Svendsen et al., 1999), deglaciation was cyclic due to climatic forcing (Björk, 2007; Peteet, 2009). Two warming periods $\sim 14.7$ and $11.5 \mathrm{kyr} B P$ in the northern Atlantic region (Renssen and Isarin, 2001; Grachev and Severinghaus, 2005) significantly changed the mass balance of FIS and eventually contributed to the rebound of the crust (Stewart et al., 2000; see Alpine rebound in Norton and Hampel, 2010). Due to lithospheric plate stresses and glacio-isostatic rebound, high-magnitude $\left(M_{\mathrm{w}} \approx 7-8.2\right)$ postglacial fault deformations are common features in the northern Fennoscandian plate (Arvidsson, 1996, Wu et al., 1999; Olesen et al., 2004; Lagerbäck and Sundh, 2008; Lund et al., 2009; Kukkonen et al., 2010, Fig. 1). According to the subsidence-rebound model of Stewart et al. (2000), the occurrence of postglacial faults (PGFs) includes bending of the crust that causes stress at the edge of the receding ice sheets. Hence, the ice-marginal terrains are subjected to seismic events. The model predictions by Wu et al. (1999) suggest that the onset of fault activity started at $15 \mathrm{kyr} B P$, and the maximum fault instability was reached at $13-10 \mathrm{kyr} B P$ in Fennoscandia. With regard to the northern Fennoscandian fault zones (Roberts et al., 1997), there is good reason to suspect that these (fault) lines have reactivated during the recession of the FIS and eventually triggered intra-plate seismic events in the region (Arvidsson, 1996; Wu et al., 1999; Olesen et al., 2004). Mass flows of the offshore sediments in the Norwegian fjords provide evidence of at least three separate large-magnitude earthquakes during the period 13.5-10 kyr BP (Bøe et al., 2004; Olesen et al., 2004). Therefore, on the basis of coincidental time stratigraphy, one 


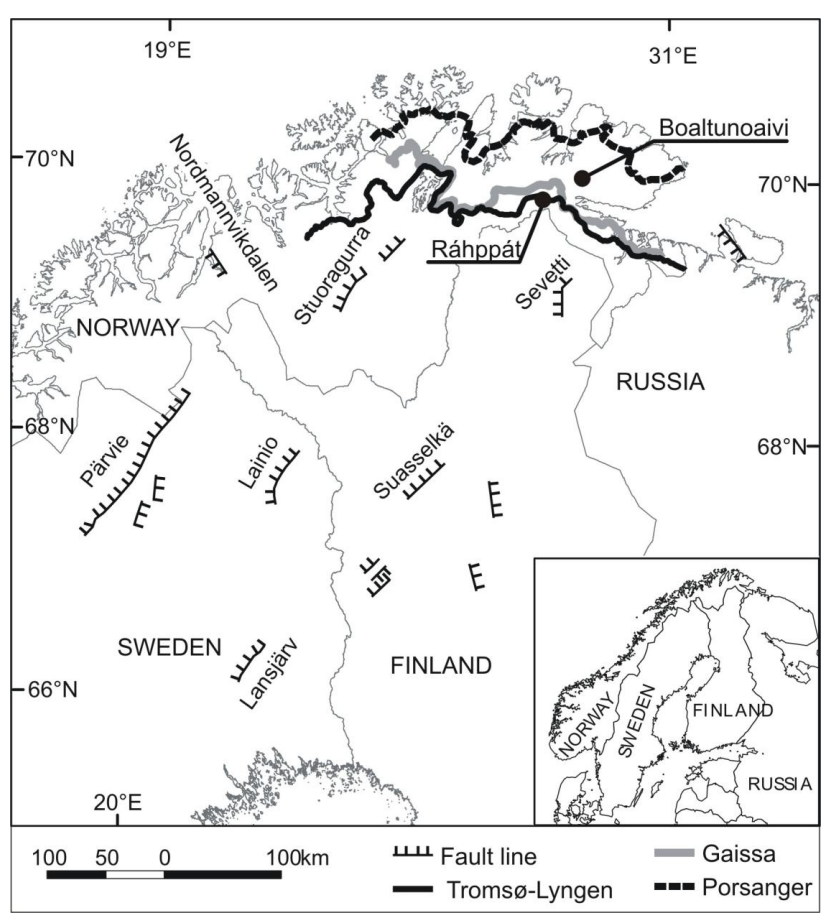

Figure 1. Location map showing major ice-marginal moraines in Finnmark, northern Norway (after Sollid et al., 1973; Olsen et al., 1996). Maskevarri Ráhppát study site and morphologically similar moraine field on Boaltunoaivi fell indicated. The Troms $\emptyset$-Lyngen moraines were formed $\sim 12.5-12 \mathrm{ky} \mathrm{BP}$ and the Skarpnes event, possibly correlative to the Porsanger sub-stage, $\sim 14.3-14.1 \mathrm{ky} \mathrm{BP}$ (Sollid et al., 1973; Vorren and Plassen, 2002). Locations of the northern Fennoscandian postglacial fault lines according to Tanner (1930), Kujansuu (1964), Lundqvist and Lagerbäck (1976), Lagerbäck (1990, 2008), Dehls et al. (2000) and Sutinen et al. (2009a).

may argue that earthquakes may have also played an important role in subglacial deformation (Sutinen et al., 2009a, 2014b). The morphological and electrical-sedimentary studies on ráhppát, forming distinctive landform complexes in Finnmark, northern Norway, may bring new insight into paleo-seismicity.

Maskevarri Ráhppát (Fig. 1) was selected on the basis that it has been (i) classified as having formed during the Troms $\varnothing$ Lyngen sub-stage in Finnmark (Sollid et al., 1973), (ii) described as ice marginal moraine in the geomorphology map produced by the Nordkalott Project (1986), and (iii) classified as ablation hummocky moraine in the general scale (1:500 000) Quaternary map by Olsen et al. (1996). We studied whether topographic position, elevation, geomorphology and electrical-sedimentary anisotropy of ridges in Maskevarri Ráhppát support the concepts presented for the YD moraines: (i) compressive shearing similarly to present-day polar and periglacial climate (Sollid et al., 1973; Sollid and Sørbel, 1988), (ii) englacial thrusting by polythermal glaciers such as in Svalbard (Graham and Midgley, 2000; see Boulton et al., 1999), or (iii) deformation of former supraglacial debris by readvancing ice in a similar way as those in a temperate glacial regime in SW Norway and Iceland (Bennett et al, 2004; Lukas, 2005). The alternative hypothesis was that (iv) the ráhppát is associated with late glacial fault instability and subglacial deformation caused by earthquake(s).

\section{Morpho-sedimentary analysis}

Orthophotos (Norkart Geoservice AS and Geovekst) and satellite images (Landsat TM images Google Earth; virtual globe www.norgei3D.no) as well as maps of geomorphology and ice flow indicators produced by the Nordkalott Project (1986) and the Geological Survey of Norway (Olsen et al., 1996) were used to interpret the landform complex associated with the terrain demarcated by the Troms $\varnothing$-Lyngen substage of the Younger Dryas in Finnmark, northern Norway (Solid et al., 1973; Nordkalott Project, 1986; Sollid and Sørbel, 1988; Olsen et al., 1996).

The ráhppát on Maskevarri fell, centered at $70^{\circ} 09^{\prime} \mathrm{N}$ and $27^{\circ} 56^{\prime} \mathrm{E}$ and $5-10 \mathrm{~km}$ north of the Finnish-Norwegian border, is an area $(5 \mathrm{~km}$ long and $3 \mathrm{~km}$ wide) of rough (stony/bouldery) ridges and hummocks separated by a number of ponds and lakes and bordered by arc-formed/sinusoidal ridges, extending diagonally to the Maskejohka river valley (58-74 ma.s.l.; Fig. 2). Ráhppát is located on the SW-facing slope at elevations from 285 to $240 \mathrm{~m}$ a.s.l., whereas the top of the Maskevarri fell reaches $308 \mathrm{~m}$ a.s.l. The region is represented by the lowermost nappes in the Caledonian mountain chain in Finnmark, so called Gaissa Nappe Complex, and the bedrock is composed of Neoproterozoic quartzites, sandstones and dolomites (Roberts et al., 1997). We also paid attention to the network of mounds and ridges, morphologically similar to Maskevarri Ráhppát, on Boaltunoaivi fell of Varanger Halvøya (peninsula). Boaltunoaivi is located between the Porsanger and Gaissa lines (Sollid et al., 1973; Olsen et al., 1996; location in Fig. 1).

In the field we utilized in situ azimuthal electrical conductivity $\left(\sigma_{\mathrm{a}}\right)$ measurements to determine sedimentary anisotropy of the sinusoidal ridges bordering the main section of the ráhppát field on the Maskevarri fell (Fig. 3). The flow paths of pore water predominantly follow preferred anisotropic (hydraulic) structures (Taylor and Fleming, 1988; Friedman, 2005). We targeted $\sigma_{\mathrm{a}}$-anisotropy surveys on an unsaturated (vadose) zone of the ridges, and within this zone the sediments are considered to be a three-phase, solid-air-water system. Minerals of Neoproterozoic quartzites (Roberts et al., 1997) constituting the solid phase were considered non-conducting, and $\sigma_{\mathrm{a}}=0$ applies to air in the pore spaces; hence the dominant conductive phase was the pore-water solution conductivity (Friedman, 2005). Non-spherical particles in glaciogenic sediments typically are preferentially aligned. Hence, for example, tills are anisotropic in nature, and their $\sigma_{\mathrm{a}}$ depends on the direction in which it is measured (Friedman, 2005). The $\sigma_{\mathrm{a}}$ 


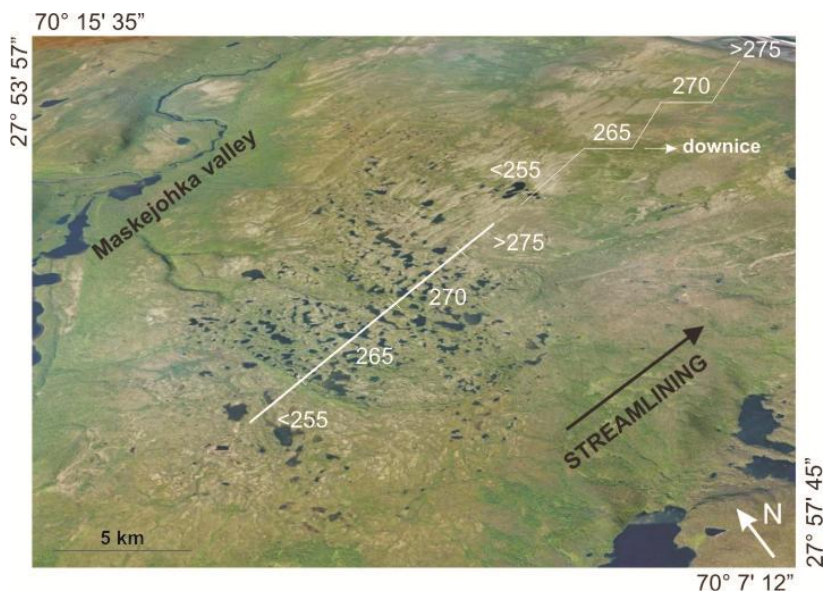

Figure 2. A 3-D image of the Maskevarri Ráhppát, Finnmark, northern Norway (Norkart Geoservice AS and Geovekst). The streamlining towards Tanafjord shown by black arrow.

anisotropy of glaciofluvial materials, sediment mass flow deposits or tills parallels with the depositional fabric derived either from active-ice movement, mass or meltwater flow (Sutinen et al., 2009b). In addition, structurally complex landforms, such as Rogen moraine and/or glacially streamlined flutings, possessing time-statigraphical information about the glacial episodes, can be revealed with $\sigma_{\mathrm{a}}$-anisotropy surveys (Sutinen et al., 2010a, b). Therefore, the measurements of azimuthal electrical conductivity can assist in attaining a better understanding of the genesis of the ráhppát complex in Finnmark.

We measured azimuthal electrical conductivity inductively with EM31 and EM38 devices (Geonics Ltd., Mississauga, Canada) at three sites on the main sinusoidal ridges bordering the main section of the ráhppát field on the Maskevarri fell (locations in Fig. 3). The sites on the ridge were selected on the basis that the anticipated pseudoreplication, estimated to be on the order of $<100 \mathrm{~m}$, should be avoided by using lateral offsets $>100 \mathrm{~m}$ (Sutinen et al., 2009b, a). At each site, the azimuthal $\sigma_{\mathrm{a}}$ was obtained using $10^{\circ}$ lateral increments. For each increment a sum of hundred samples were stored in an Allegro CX logger (Juniper Systems Inc, Logan, UT USA). The skin depth (penetration) was roughly as follows: EM38V (vertical coil configuration) $0-1.5 \mathrm{~m}, \mathrm{EM} 31 \mathrm{H}$ (horizontal coil configuration) 0-3 m, and EM31V 0-6 m, respectively. The measured data were visualized as polar plots (Grapher 4.0, Golden Software).

\section{Results}

\subsection{Morphology}

Maskevarri Ráhppát is dominated by esker-like ridges, $2-10 \mathrm{~m}$ in height and with sinusoidal morphology and stony/blocky surface, and appears as an anastomosing esker
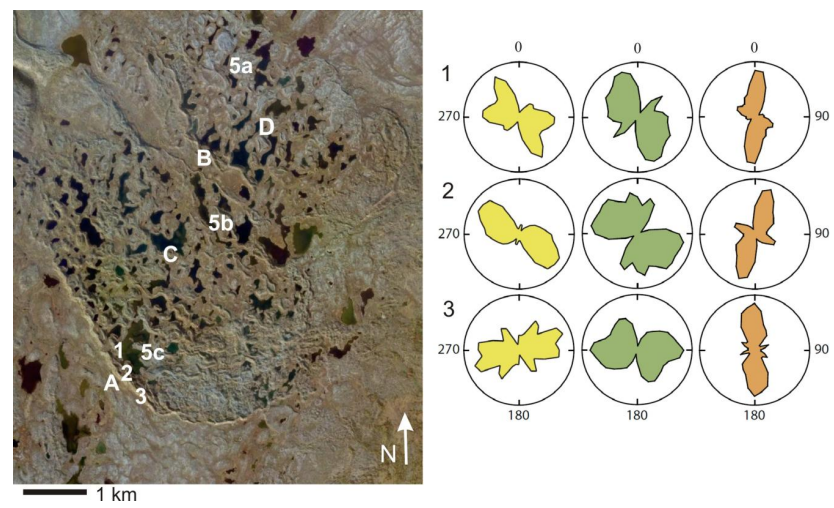

Figure 3. Locations of the electrical-sedimentary measuring sites (1-3) on Maskevarri Ráhppát, Finnmark, northern Norway (Norkart Geoservice AS and Geovekst), and device-specific azimuthal electrical conductivity presented for Geonics EM31V (0-6 m), EM31H (0-3 m), and EM38V (0-1.5 m) coil configurations. Numbers A-D refer to photographs shown in Figs. 4 and $5 \mathrm{a}-\mathrm{c}$ to air photos shown in Fig. 5.

network (Fig. 3). The esker pattern signifies that the ráhppát landforms have originated in wet-base conditions beneath the ice. Surface roughness (stones/boulders) of the ráhppát is ubiquitous (Figs. 3 and 5). Stones and boulders, up to $30 \mathrm{~m}^{3}$ in size, can be found both on the top and bottom of the ridges and mounds. In the southern section of the ráhppát, the boulder fields appear to be lag formed (Fig. 5c), yet only the gullies near the Maskejohka valley are truly meltwater erosion forms. The lags and gullies indicate wet-base conditions at the time of ráhppát formation.

The ráhppát is typified by $\sim 500$ small lakes, ponds and puddles (Figs. 2-4) that are arranged at three different elevation levels on the SW slope of the Maskevarri fell. The data indicate that the slightly sloping planes range from 285 $280 \mathrm{~m}$ a.s.l. in the upper part of the Maskevarri fell to 270 $260 \mathrm{~m}$ in the mid-level and $<260 \mathrm{~m}$ a.s.l. at the lower part of the field. The differences between the water levels of the lakes on the adjacent planes may be on the order of 5-10 m (Fig. 4). The sinusoidal "bordering ridges" with $5-10 \mathrm{~m}$ in height form the junction between the elevations. We suggest that the "hanging" ponds indicate disruption of bedrock, the scarps tentatively being created through earthquakes (see Lagerbäck and Sundh, 2008). If these ponds were part of the formation of the main YD sub-stage (Troms $\varnothing$-Lyngen), they should be much more abundant all over Finnmark than they are.

\subsection{Electrical-sedimentary anisotropy}

The azimuthal $\sigma_{\mathrm{a}}$ data indicated that the sediments in the cores of the ridges were oriented more or less parallel to ridges. The EM $31 \mathrm{~V}$ data, referring to a depth range of $0-6 \mathrm{~m}$, indicated west-northwest maximum anisotropy (Fig. 3). In a similar manner, the EM31H data, referring roughly to a depth 

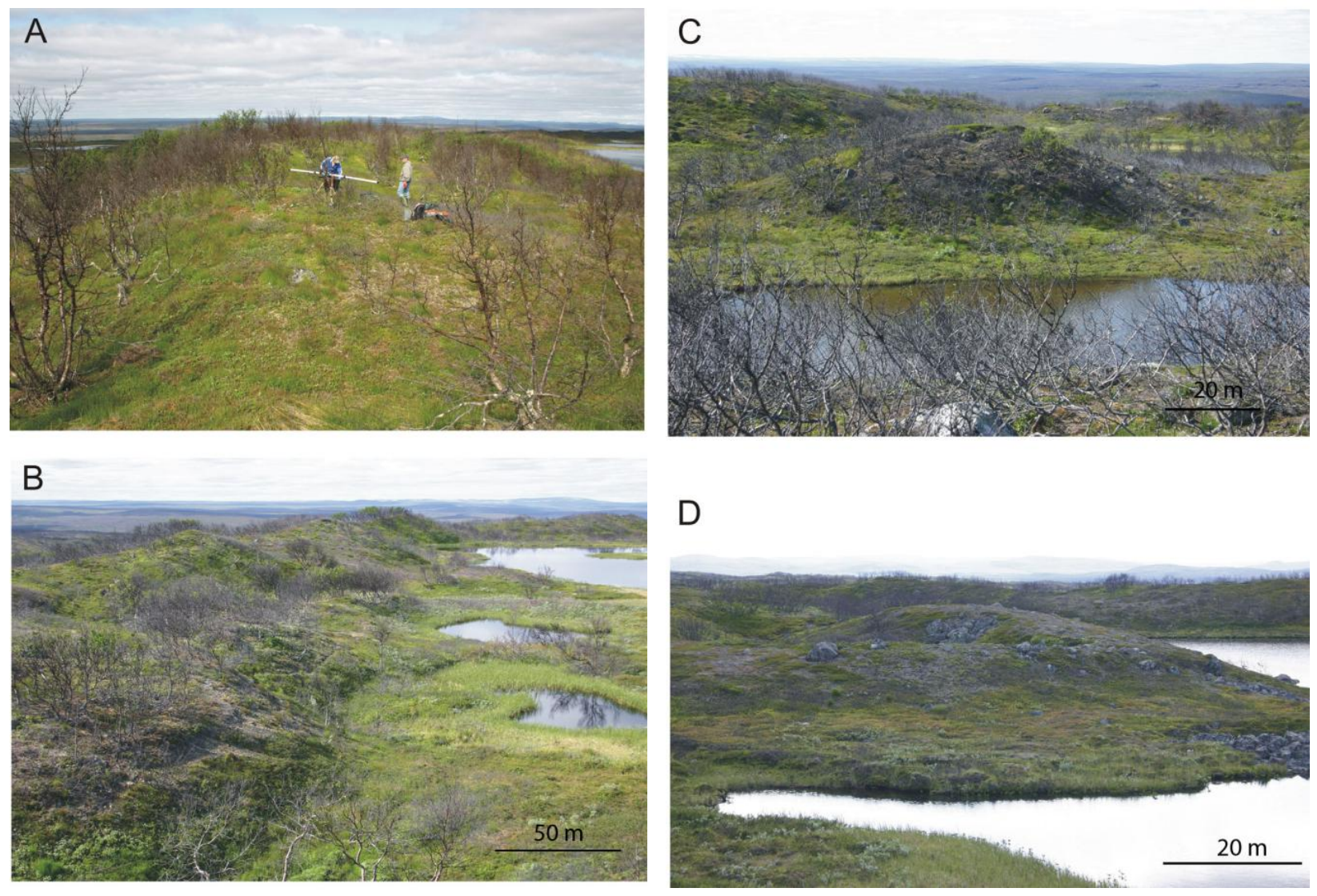

Figure 4. (A) The south-western border ridge $\left(70^{\circ} 08^{\prime} 54^{\prime \prime} \mathrm{N}\right.$ and $\left.27^{\circ} 54^{\prime} 52^{\prime \prime}\right)$ on Maskevarri Ráhppát, Finnmark, northern Norway. Note the elevation difference between the hummocky field (right) and gentle undulating tundra (left) is about $12 \mathrm{~m}$. (B) The north-eastern border ridge $\left(70^{\circ} 09^{\prime} 37^{\prime \prime} \mathrm{N}\right.$ and $\left.27^{\circ} 56^{\prime} 25^{\prime \prime}\right)$ on the ráhppát. Note the elevation difference between the hummocky fields on both sides of the ridge is about $10 \mathrm{~m}$. (C) An example of hummocky moraine terrain on middle part of the ráhppát $\left(70^{\circ} 09^{\prime} 14^{\prime \prime} \mathrm{N}\right.$ and $\left.27^{\circ} 55^{\prime} 32^{\prime \prime}\right)$ ranging in elevation from 260 to $270 \mathrm{~m}$ a.s.l. (D) An example of hummocky moraine terrain on upper terrace of the ráhppát $\left(70^{\circ} 09^{\prime} 41^{\prime \prime} \mathrm{N}\right.$ and $\left.27^{\circ} 57^{\prime} 09^{\prime \prime}\right)$ ranging in elevation from 280 to $285 \mathrm{~m}$ a.s.l. Note the leafless birch trees/bushes due to damages of autumnal moth (Epirrita autumnata). Photos by R. Sutinen (2009).

range of $0-3 \mathrm{~m}$, clearly showed the west-northwest sedimentary anisotropic pattern. These observations indicate that the cores of the border ridges are depositional, and a northwestward sediment (mass) flow heading diagonally towards the Maskejohka valley (Figs. 2-4). In addition, the bordering ridges are interconnected to meltwater gullies in the valley suggesting generation through short-lived conduit infills (Sutinen et al., 2009b). In the case of the transverse-to-ridge sedimentary origin, the sedimentary anisotropy should be, according to streamlined features, towards northeast (i.e., from a sector of $200-245^{\circ}$ ). No such orientation was found. In the case of the ridges here, the maximum sedimentary anisotropy matched the ridge-crestline trends similarly to sinusoidal moraine ridges built of sediment flow deposits in Finnish Lapland (Sutinen et al., 2009a). The polar plots of maximum EM38V anisotropy $(0-1.5 \mathrm{~m})$ appeared to be north/northeast in a sector $180-200^{\circ}$, eventually due to post-depositional slope reworking as particularly seen in the foreground of Fig. 4b.

\section{Discussion}

\subsection{Ráhppát and ice flow}

The ráhppát field is oriented diagonally with respect to glacial lineations on the SW slope of Maskevarri fell (Fig. 2); hence it clearly post-dates the active-ice movement, and no surface evidence of active ice remoulding features can be found (cf. Rogen moraine in Sutinen et al., 2010a). Push moraines, such as Younger Dryas end moraines (YDEMs), tend to be mantled with till cover and often carrying signs of glaciotectonic deformations in the sediments (Andersen et al., 1995; Lundqvist, 1995). Also, reports (e.g., from the Canadian plains) indicate that the late Wisconsinan push moraines show evidence of glacier overriding (Evans et 

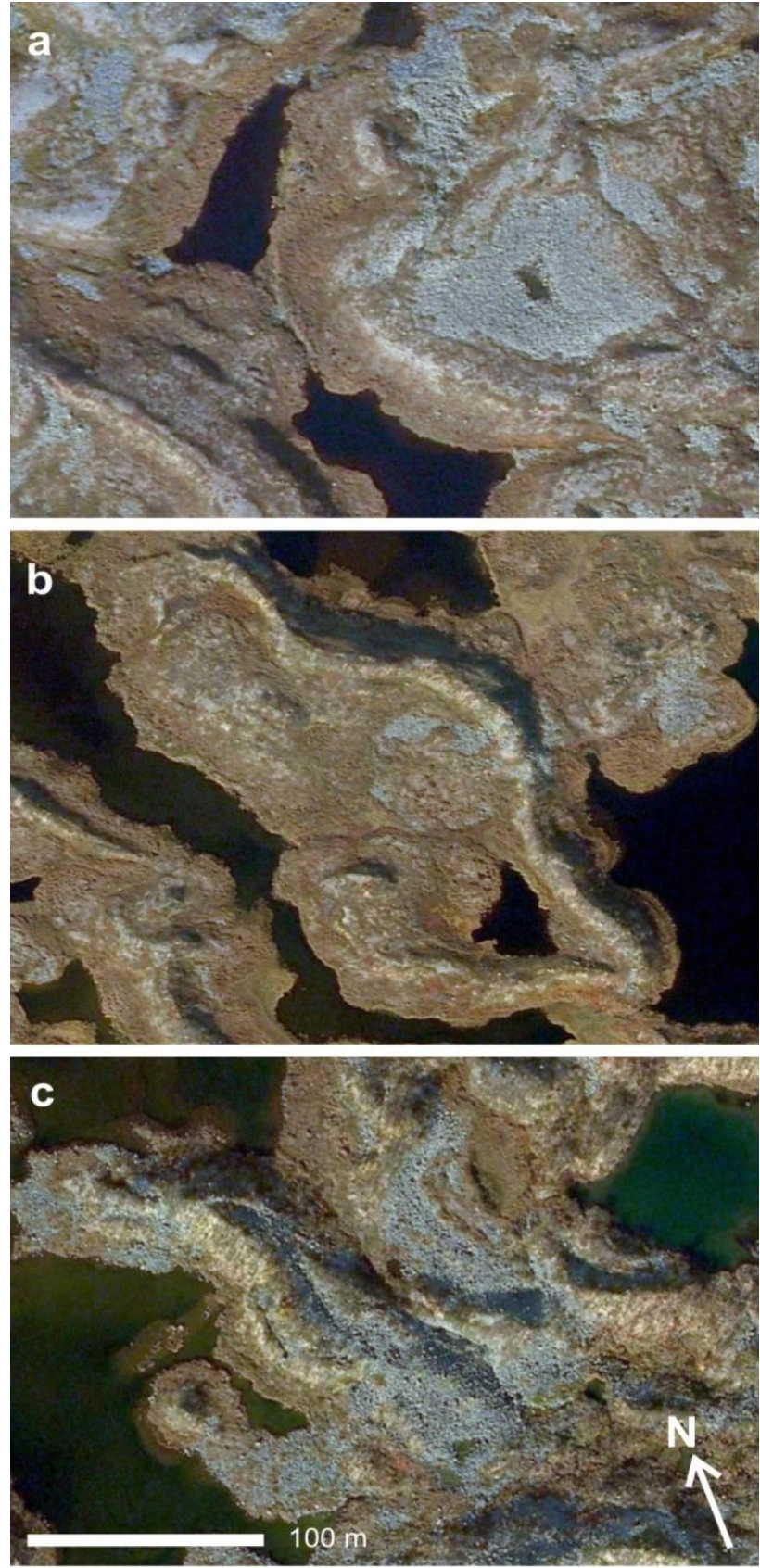

Figure 5. Air photos (Norkart Geoservice AS and Geovekst) showing examples of surface stoniness of the Maskevarri Ráhppát, Finnmark, northern Norway. Locations indicated in Fig. 3.

al., 2014). Many of the YDEMs in Fennoscandia are built of massive distorted glaciofluvial sediments (Andersen et al., 1995; Lundqvist, 1995), yet some parts of the Middle Swedish end moraines are predominantly composed of glaciotectonically deformed clays (Johnson et al., 2013). The position and electrical-sedimentary anisotropy of ráhppát on the SW slope of the Maskevarri fell does not fit into the concept of ice-marginal moraines, generated through englacial thrusting or compression (Sollid and Sørbel, 1988). The orientation of the YD main stage ice margin (Sollid et al., 1973) should have been roughly WNW-ESE, according to up-ice drumlin orientation from the southwest (Nordkalott Project, 1986; Olsen et al., 1996; Fig. 1). Therefore, the azimuthal EM data support other mechanisms for the ráhppát than those proposed for the YD moraines, such as compressive shearing (Sollid et al., 1973; Sollid and Sørbel, 1988), englacial thrusting (Graham and Midgley, 2000) or the concept by Lukas (2005), according to which former supraglacial debris had been subglacially deformed under readvancing ice margin.

\subsection{Esker network and periglacial features}

Based on the anastomosing esker network (Fig. 3), we contend that Maskevarri Ráhppát was formed in subglacial wetbase conditions. Although arborescent and anastomosing eskers have been recognized as meltwater-produced forms (Banerjee and McDonald, 1975; Clark and Walder, 1994; Sutinen et al., 2009a), the mechanism of the "pressurized outburst" esker ridges in the ráhppát field is different from conventional time-transgressive evolution of eskers (Banerjee and McDonald, 1975). Squeezing of water-soaked material into the basal cavities of the ice (Fig. 6) is able to form hummocky moraines as described by Hoppe (1952), yet transition from hummocky moraines to esker networks needs wet-base conditions. Indeed, Maskevarri Ráhppát has similarities with anastomosing esker - Pulju moraine complex associated with subglacial Kultima fault, recently described in western Finnish Lapland (Sutinen et al., 2014b). Research in Canada has revealed that subglacial lake outbursts are able to create broad and extensive corridors of glaciofluvial landforms, eskers in particular (Rampton, 2000; Utting et al., 2009). Smaller-scale networks of anastomosing eskers have been reported from Utsjoki, some $50 \mathrm{~m}$ south of Maskevarri (Sutinen et al., 2009a). Maskevarri Ráhppát, however, is a small (5 km long, $3 \mathrm{~km}$ wide) field of sinusoidal eskers and hummocks of the SE-facing fell slope at an elevation of 240 $285 \mathrm{~m}$ a.s.l. (Figs. 2-3); hence a subglacial lake outburst origin seems unlikely. Instead, water required for the genesis Maskevarri esker field may have originated from lithosphere beneath the ice. It has been revealed that paleoseismic impacts have contributed to lithospheric hydromechanics and forebulge deformations (Brandes et al., 2012; Neuzil, 2012), and even minor recent earthquakes in Fennoscandia are able to create large amounts of groundwater pouring out of the PGFs (Dehls et al., 2000). We propose that the triggering and forcing mechanism for the genesis of the esker network likely had been a late-glacial seismic event, either glacial (Ekström et al., 2006; Nettles and Ekström, 2010; West et al., 2010) or PGF earthquake (Arvidsson, 1996, Wu et al., 1999; Olesen et al., 2004).

Morphology of some mounds or arcuate ridges within the ráhppát (Figs. 4c-d and 5a) may resemble pingos or palsas 


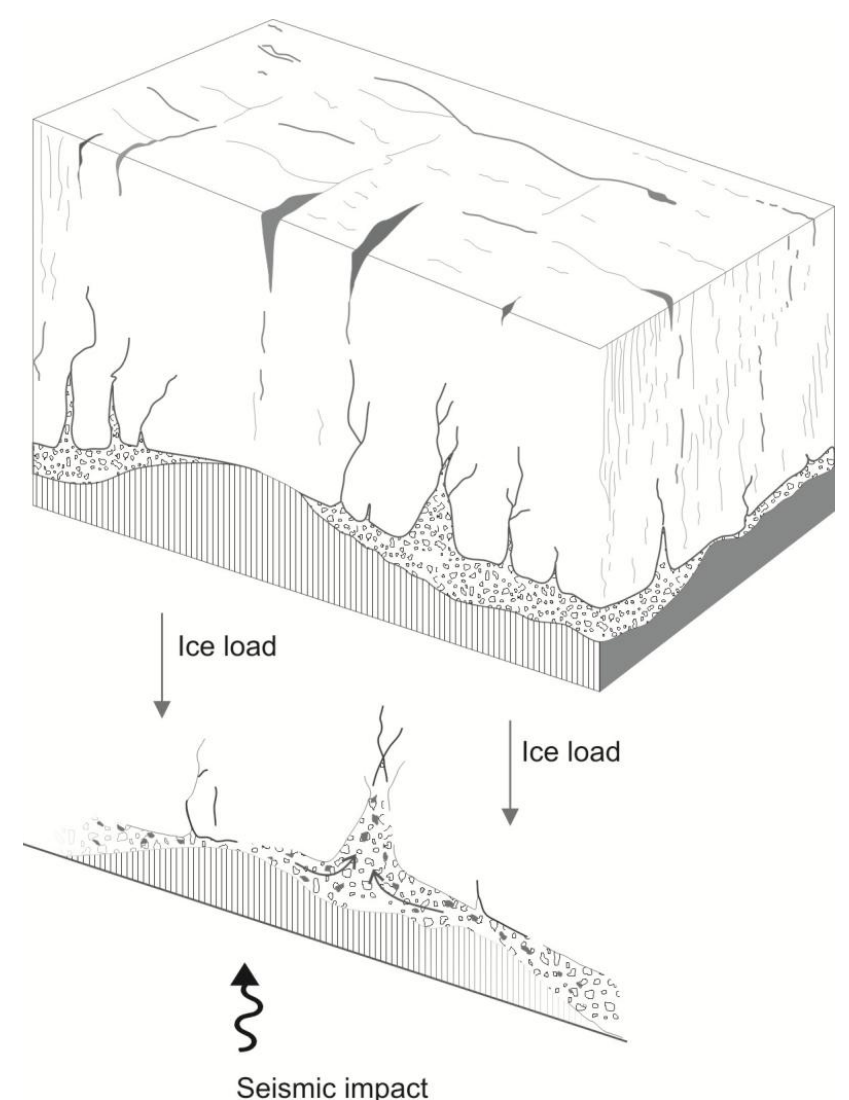

Figure 6. Diagram illustrating the proposed mechanism forming the ridges in the Maskevarri Ráhppát. Adopted from Hoppe (1952).

developed in periglacial conditions found on flat terrains (Seppälä, 2011; Jones et al., 2012; Wetterich et al., 2012). The development of pingos (e.g., in Alaska) has been shown to date back even to 50-40 kyr BP (Wetterich et al., 2012), and they are of hydrostatic origin predominantly located on drained lake basins and underlain by thick eolian sand deposits (Jones et al., 2012). Palsas, on the other hand, are peat-covered mounds with a permanently frozen core ranging from 0.5 to $7 \mathrm{~m}$ in height and from 2 to $150 \mathrm{~m}$ in diameter in northern Finland (Seppälä, 2011). The nearest palsa field in the Finnish side, Vaisjeäggi (Tabuchi and Seppälä, 2012), is located about $30 \mathrm{~km} \mathrm{SW}$ from the study site, yet no palsas are to be found in Maskevarri Ráhppát. We contend that the surface roughness of ráhppát ridges and mounds (Figs. 45) indicates a mechanism other than freeze-thaw cycling in continuous permafrost conditions during the Holocene.

Numerous ponds and lakes in Maskevarri Ráhppát, totaling 500, are very irregular in shape (Figs. 2-3). In comparison, synthetic aperture radar (SAR) studies (e.g., in the North Slope, Alaska) indicate a more or less organized pattern of the talik lakes (Grunblatt and Atwood, 2014). In a similar way, the flat terrain pattern of the thermokarst lakes in eastern Siberia is dynamic, yet having been developed on soft sedi- ments since 13-12 kyr BP (Morgenstern et al., 2013). Mountain permafrost is commonly found in Norway (Lilleøren et al., 2012), and many of the mountain rockslide deformations in northern Norway are permafrost-controlled (Blikra and Christiansen, 2014). The morphology of the rockslide talus deformations (Blikra and Christiansen, 2014) is, however, dissimilar to bouldery esker ridges and mounds in Maskevarri Ráhppát (Figs. 4-5). According to temperature estimations by Lilleøren et al. (2012), permafrost may have existed in the Maskevarri area during the Little Ice Age, but it is thawed today. No evidence has been found to indicate that permafrost persisted through the Holocene in the Maskevarri area (Lilleøren et al., 2012). The lack of Holocene permafrost in the study area (Lilleøren et al., 2012) suggests that the development of the tightly clustered lakes and ponds in the Maskevarri Ráhppát is not associated with periglacial talik environment.

Morphologically similar to Maskevarri Ráhppát, a network of eskers and moraine ridges and mounds $(2.2 \mathrm{~km}$ times $1.6 \mathrm{~km}$ in size) is present at Boaltunoaivi fell (centered at $70^{\circ} 17^{\prime} \mathrm{N}$ and $29^{\circ} 01^{\prime} \mathrm{E}$ ). The field is on the SE slope of the Boaltunoaivi fell, ranging from 315 to $240 \mathrm{~m}$ a.s.l. in elevation (location in Fig. 1). The geographical position of this field between the Porsanger and Gaissa lines, $80 \mathrm{~km}$ apart (Sollid et al., 1973; Olsen et al., 1996), suggests that morphologically similar chaotic landforms may have been created during different times within the deglaciation of the FIS. This time lag between the Porsanger sub-stage and the main sub-stage, about two thousand years, fits into the time frame of the maximum fault instability in northern Fennoscandia, $\sim 13.5-10$ kyr BP (Wu et al., 1999; Lund et al., 2009). Therefore, Maskevarri Ráhppát and Boaltunoaivi fields (see locations in Fig. 1), similar in geomorphology, may have similar genesis yet different time-stratigraphic position.

\subsection{Paleoseismicity}

Late Weichselian ice-sheet mass-balance fluctuations, due to the fast melting rate and retreat of the FIS margin (Svendsen et al., 1999), eventually released isostatic crustal rebound and triggered large-scale seismic events (Wu et al., 1999; Olesen et al., 2004). The NE-SW trending geometry of these highmagnitude $\left(M_{\mathrm{w}} \approx 7-8.2\right)$ late or PGF deformations emphasize lithospheric plate stresses (Arvidsson, 1996; Wu et al., 1999; Olesen et al., 2004; Lund, 2005; Lund et al., 2009). The length of the NE-SW trending PGFs varies from a few kilometers to more than $150 \mathrm{~km}$ (Olesen et al., 2004; Lagerbäck and Sundh, 2008). Recent observations suggest that, for example, Lainio-Suijavaara PGF in northern Sweden and Palojärvi PGF in northern Finland may be linked together (Sutinen et al., 2014b). In addition, new faults have been described in middle Sweden - so-called Bolnäs fault (Smith et al., 2014) and Lake Vättern fault in southern Sweden (Jakobsson et al., 2014). These observations suggest that PGFs may be more extensive features than previously recognized. 
In Finnmark and the Kola Peninsula, the major lineaments are trending WNW-ESE (Roberts et al., 1997). Following this geometry, Tanner (1930) described PGF in Kalastajasaarento (Rybachy Peninsula, Kola) with the upthrown block facing NE. In a similar way, recent high-resolution bathymetric data along Varangerfjorden, Finnmark (Ottesen et al., 2008, their Fig. 9), show the sea-bottom expression of the main fault of the Trollfjord-Komagelv Fault Zone (Roberts et al., 1997). This fault feature cuts and post-dates the ice stream mega-scale glacial lineations, hence possibly being PGF in origin. In addition, similar geometry has been reported for Nordmannvikdalen fault, northern Norway (Dehls et al., 2000) and for Kultima fault in NW Finnish Lapland (Sutinen et al., 2014b). The elevation steps in Maskevarri Ráhppát also follow the WNW-ESE trending geometry with the upthrown blocks facing NE just in a similar way as those features in Kalastajasaarento as well as in the bottom of Varagerfjord (Tanner, 1930; Ottesen et al., 2008) in concordance with lineament pattern in Finnmark (Roberts et al., 1997).

In the Norwegian fjords at least three separate largemagnitude YD earthquakes have resulted in mass flows of the offshore sediments concurrently with glacial events within northern and northwestern Norway (Olsen et al., 1996; Vorren and Plassen, 2002; Bøe et al., 2004; Olesen et al., 2004). Paleoseismicity may have played an important role in subglacial deformation (Sutinen et al., 2009a, b), yet more detailed morphological evidence through airborne lidar would be particularly important in the future (Sutinen et al., 2014a, b). Due to the surface roughness, numerous hyperbola reflections in the ground-penetrating radar data (see, e.g., Utting et al., 2009) make the GPR structural sediment surveys challenging. Even though seismically induced deformations, seismites (Lagerbäck and Sundh, 2008; Brandes and Winsemann, 2013), are typical of soft sediments, further sedimentological studies are needed to support the neotectonic origin of ráhppát on Maskevarri fell.

\section{Conclusions}

The geomorphology of Maskevarri Ráhppát with $\sim 500$ small lakes, ponds and puddles on three terraces differs from the onshore and offshore YD moraines in the Norwegian fjords often exhibiting glacial tectonic overridden Allerød deposits as well as pushing features on their proximal sides, hence showing a glacial readvance during the main YD phase. Even though positioned on the line of the main (Tromsø-Lyngen) sub-stage, the Maskevarri Ráhppát has no remoulding features to support the ice readvance during the cold reversal. The electrical-sedimentary anisotropy in the core of the bordering ridges, parallel-to-ridge trends and towards west-northwest, is more or less orthogonal with respect to northeastward ice flow towards the Tana fjord. Therefore, the mechanisms such as compressive shearing, englacial thrusting or deformation of former supraglacial debris by readvancing ice, as proposed for the genesis of the YD moraines, do not apply to Maskevarri Ráhppát. The time lag between the Porsanger sub-stage and the main substage, about two thousand years, is coincidental with the increased neotectonic instability in northern Fennoscandia. Therefore, Maskevarri Ráhppát and Boaltunoaivi fields, similar in geomorphology, appear to have similar genesis yet different time-stratigraphic position. Earthquakes induced by the glacio-isostatic rebound potentially deformed the subglacial bed and created ráhppát landforms at Maskevarri and Boaltunoaivi sites in Finnmark.

Acknowledgements. The present paper was a part of the project Forest Soils and Global Change at the Geological Survey of Finland focusing, for example, on vadose zone sedimentary anisotropy. Editorial help by Viena Arvola, Paula Haavikko and Päivi Heikkilä is highly appreciated. Kent Middleton revised the language. The constructive comments by Editor Christophe Pascal as well as reviewers Michel Sebrier and Christian Brandes significantly improved the paper.

Special Issue: "Lithosphere-cryosphere interactions"

Edited by: M. Poutanen, B. Vermeersen, V. Klemann, and C. Pascal

\section{References}

Andersen, B. G., Mangerud, J., Sørensen, R., Reite, A., Sveian, H., Thoresen, M., and Bergström, B.: Younger Dryas ice-marginal deposits in Norway, Quaternary Int., 28, 147-169, 1995.

Arvidsson, R.: Fennoscandian earthquakes: whole crustal rupturing related to postglacial rebound, Science, 274, 744-746, 1996.

Banerjee, I. and McDonald, B. C.: Nature of esker sedimentation, Special Publications of the Society of Economic Paleontologists and Mineralogists, Tulsa, 23, 132-154, 1975.

Bennett, M. R., Huddard, D., Waller, R. I., Cassidy, N., Tomio, A., Zukowskyj, P., Midglet, G., Cook, S. J., Gonzales, S., and Glasser, N. F.: Sedimentary and tectonic architecture of a large push moraine: a case study from Hagafellsjökull-Eystri, Iceland, Sediment. Geol., 172, 269-292, 2004.

Blikra, L. H. and Christiansen, H. H.: A field-based model of permafrost-controlled rockslide deformation in northern Norway, Geomorphology, 208, 34-49, 2014.

Boulton, G. S., van der Meer, J. J. M., Beets, D. J., Hart, J. K., and Ruegg, G. H. J.: The sedimentary and structural evolution of a recent push moraine complex: Holmstrømbreen, Spitsbergen, Quaternary Sci. Rev., 18, 339-371, 1999.

Bøe, R., Longva, O., Lepland, A., Blikra, L. H., Sønstegaard, E., Haflidason, H., Bryn, P., and Lien, R.: Postglacial mass movements and their causes in flords and lakes in western Norway, Norw. J. Geol., 84, 35-55, 2004.

Brandes, C., Winseman, J., Roskosch, J., Meinsen, J., Tanner, D. C., Frechen, M., Steffen, H., and Wu, P.: Activity along the Osning Thrust in Central Europe during the Lateglacial: ice-sheet and lithosphere interactions, Quaternary Sci. Rev., 38, 49-62, 2012.

Brandes, C. and Winsemann, J.: Soft-sediment deformation structures in NW germany caused by late Pleistocene seismicity, Int. 
J. Earth Sci., 102, 2255-2274, doi:10.1007/s00531-013-0914-4, 2013.

Clark, P. U. and Walder, J. S.: Subglacial drainage, eskers, and deforming beds beneath the Laurentide and Eurasian ice sheets, Geol. Soc. Am. Bull., 106, 304-314, 1994.

Dehls, J. F., Olesen, O., Olsen, L., and Blikra, L. H.: Neotectonic faulting in northern Norway, the Stuoragurra and Nordmannvikdalen faults, Quaternary Sci. Rev., 19, 1447-1460, 2000.

Ekström, G. Nettles, M., and Tsai, V. C.: Seasonality and increasing frequency of Greenland glacial earthquakes, Science, 311, 17561758, 2006.

Evans, J. A., Young, N. J. P., and ÓCofaigh, C.: Glacial geomorphology of terrestrial-terminating fast flow lobes/ice stream margins in the southwest Laurentide Ice Sheet, Geomorphology, 204, 86-113, 2014.

Friedman, S. P.: Soil properties influencing apparent electrical conductivity; a review, Comput. Electron. Agr., 46, 45-70, 2005.

Grachev, A. M. and Severinghaus, J. P.: A revised $+10 \pm 4{ }^{\circ} \mathrm{C}$ magnitude of the abrupt change in Greenland temperature at the Younger Dryas termination using published GISP2 gas isotope data and air thermal diffusion constants, Quaternary Sci. Rev., 24, 513-519, 2005.

Graham, D. J. and Midgley, N. G.: Moraine mound formation by englacial thrusting: the Younger Dryas moraines of Cwm Idwal, North Wales, in: Deformation of Glacial materials, edited by: Maltman, A. J., Hubbard, B., and Hambrey, M. J., Geological Society, London, Spec. Publ., 176, 321-336, 2000.

Grunblatt, J. and Atwood, D.: Mapping lakes for winter liquid water availability using SAR on the North Slope of Alaska, Int. J. Appl. Earth Obs., 27, 63-69, 2014.

Hoppe, G.: Hummocky moraine regions with special reference to the interior of Norrbotten, Geogr. Ann., 34, 1-72, 1952.

Jakobsson, M., Björk, S., O’Regan, M., Flodén, T., Greenwood, S. L., Swärd, H., Lif, A., Ampel, L., Koyi, H., and Skelton, A.: Major earthquake at the Pleistocene-Holocene transition in Lake Vättern, southern Sweden, Geology, 42, 379-382, doi:10.1130/G35499.1, 2014.

Johnson, M., Benediktsson, Í.Ö., and Björklund, L.: The Ledsjö end moraine - a subaquatic push moraine composed of glaciomarine clay in central Sweden, P. Geologist. Assoc., 124, 738-752, 2013.

Jones, B. M., Grosse, G., Hinkel, K. M., Arp, C. D., Walker, S., Beck, R. A., and Galloway, J. P.: Assessment of pingo distribution and morphometry using an IfSAR derived digital surface model, western Arctic Coastal Plain, Northern Alaska, Geomorphology, 138, 1-14, 2012.

Kujansuu, R.: Nuorista siirroksista Lapissa. Summary: Recent faults in Lapland, Geologi, 16, 30-36, 1964.

Kukkonen, I., Olesen, O., Ask, M. V. S., and PFDP Working Group: Postglacial faults in Fennoscandia: Targets for scientific drilling, GFF, 132, 71-81, 2010.

Lagerbäck, R.: Late Quaternary faulting and paleoseismicity in northern Fennoscandia with particular reference to the Landsjärv area, northern Sweden. Geol. För. i Stockholm Förh., 112, 333354, 1990.

Lagerbäck, R. and Sundh, M.: Early Hololocene faulting and paleoseismicity in northern Sweden, Sver. Geol. Unders., C836, 80 pp., 2008.
Lilleøren, K. S., Etzelmüller, B., Schuler, T. V., Gisnås, K., and Humlum, O.: The relative age of mountain permafrost - estimation of Holocene permafrost limits in Norway, Global Planet. Change, 92-93, 209-223, 2012.

Lund, B.: Effects of deglaciation on the crustal stress field and implications for endglacial faulting: A parametric study of simple Earth and ice models, SKBF/KBS Technical Report 05-04, Swedish Nuclear Fuel and Waste Management Co, Stockholm, 68 pp., 2005.

Lund, B., Schmidt, P., and Hieronymus, C.: Stress evolution and fault stability during the Weichselian glacial cycle, SKBF/KBS Technical Report 09-15, Swedish Nuclear Fuel and Waste Management Co, Stockholm, 106 pp., 2009.

Lundqvist, J.: The Younger Dryas Ice-Marginal Zone in Sweden, Quaternary Int., 28, 171-176, 1995.

Lundqvist, J. and Lagerbäck, R.: The Pärve Fault: A late-glacial fault in the Precambrian of Swedish Lapland, Geol. För. i Stockholm Förh., 98, 45-51, 1976.

Morgenstern, A., Ulrich, M., Günther, F., Roesslr, S., Fedorova, I. V., Rudaya, N. A., Wettrrich, S., Boike, J., and Schirrmaister, L.: Evolution of thermokarst in East Siberian ice-rich permafrost: A case study, Geomorphology, 201, 262-379, 2013.

Nettles, M. and Ekström, G.: Glacial earthquakes in Greenland and Antarctica, Annu. Rev. Earth Pl. Sc., 38, 467-491, 2010.

Neuzil, C. E.: Hydromechanical effects of continental glaciations on groundwater system, Geofluids, 12, 22-37, 2012.

Nordkalott Project: Geological map, Northern Fennoscandia, 1.1 mill. Geological Surveys of Finland, Norway and Sweden, 1986.

Norton, K. P. and Hampel, A.: Postglacial rebound promotes glacial re-advances - a case study from the European Alps, Terra Nova, 22, 297-302, 2010.

Olesen, O., Blikra, L. H., Braathen, A., Dehls, J. F., Olsen, L., Rise, L., Roberts, D., Riis, F., Faleide, J. I., and Anda, E.: Neotectonic deformation in Norway and its implications: a review, Norw. J. Geol., 84, 3-34, 2004.

Olsen, L., Riiber, A., and Sørensen, K.: Finnmark County, Map of Quaternary Geology, scale 1:500,000 with description, Geol. Surv. Norway, 1996.

Ottesen, D., Stokes, C. R., Rise, L., and Olsen, L.: Ice-sheet dynamics and ice streaming along the coastal parts of the northern Norway, Quaternary Sci. Rev., 27, 922-940, 2008.

Peteet, D. M.: Younger Dryas, in: Encyclopedia of Paleoclimatolgy and Ancient Environments, edited by: Gornitz, V., Encyclopedia of Earth Sciences Series, Springer, 993-996, 2009.

Rampton, V. N.: Large-scale effects of subglacial meltwater flow in the southern Slave Province, Northwest Territories, Canada, Can. J. Earth Sci., 37, 81-93, 2000.

Renssen, H. and Isarin, R. F. B.: The two major warming phases of the last deglaciation at $\sim 14.7$ and $\sim 11.5 \mathrm{ka}$ cal BP in Europe: climatic reconstructions and AGCM experiments, Global Planet. Change, 30, 117-153, 2001.

Roberts, D., Olesen, O., and Karpuz, M. R.: Seismo- and neotectonics in Finnmark, Kola Peninsula and the southern Barents Sea. Part 1. Geological and neotectonic framework, Tectonophysics, 270, 1-13, 1997.

Seppälä, M.: Synthesis of studies of palsa formation underlining the importance of local environmental and physical characteristics, Quaternary Res., 75, 366-370, 2011. 
Smith, C. A., Sundh, M., and Mikko, H.: Surficial geology indicates early Holocene faulting and seismicity, central Sweden, Int. J. Earth Sci., in preparation, 2014.

Sollid, J. L. and Sorbel, L.: Influence of temperature conditions in formation of end moraines Fennoscandia and Svalbard, Boreas 17, 553-558, 1988.

Sollid, J. L., Andersen, S., Hamre, N., Kjeldsen, O., Salviksen, O., Sturød, S., Tveitå, T., and Wilhelmsen, A.: Deglaciation of Finmark, North Norway, Norsk Geografisk Tidsskrift, 27, 233-325, 1973.

Stewart, I. S., Sauber, J., and Rose, J.: Glacio-seismotectonics, ice sheets, crustal deformation and seismicity, Quaternary Sci. Rev., 19, 1367-1389, 2000.

Sutinen, R., Piekkari, M., and Middleton, M.: Glacial geomorphology in Utsjoki, Finnish Lapland proposes Younger Dryas faultinstability, Global Planet. Change, 69, 16-28, 2009a.

Sutinen, R., Middleton, M., Liwata, P., Piekkari, M., and Hyvönen, E.: Sediment anisotropy coincides with moraine ridge trend in south-central Finnish Lapland, Boreas, 38, 638-646, 2009b.

Sutinen, R., Jakonen, M., Piekkari, M., Haavikko, P., Närhi, P. and Middleton, M.: Electrical-sedimentary anisotropy of Rogen moraine, Lake Rogen area, Sweden, Sediment. Geol., 232, 181189, 2010a.

Sutinen, R., Hyvönen, E., Närhi, P., Haavikko, P., Piekkari, M., and Middleton, M.: Sedimentary anisotropy diverges from flute trends in south-east Finnish Lapland, Sediment. Geol., 232, 190197, 2010b.

Sutinen, R., Hyvönen, E., and Kukkonen, I.: LiDAR detection of paleolandslides in the vicinity of the Suasselkä postglacial fault, Finnish Lapland, Int. J. Appl. Earth Obs., 27, 91-99, 2014a.

Sutinen, R., Hyvönen, E., Middleton, M., and Ruskeeniemi, T.: Airborne LiDAR detection of postglacial faults and Pulju moraine in Palojärvi, Finnish Lapland, Global Planet. Change, 115, 24-32, 2014b.
Svendsen, J. I., Astakhov, V. I., Bolshiyanov, D. Yu., Demidov, I., Dowdeswell, J. A., Gataullin, V., Hjort, C., Hubberten, H. W., Larsen, E., Mangerud, J., Melles, M., Möller, P., Saarnisto, M., and Siegert, M. J.: Maximum extent of the Eurasian ice sheets in the Barents and Kara Sea region during the Weichselian, Boreas, 28, 234-242, 1999.

Tabuchi, H. and Seppälä, M.: Surface temperature inversion in the palsa and pounu fields of northern Finland, Polar Sci., 6, 237251, 2012.

Tanner, V.: Studier over kvartärsystemet i Fennoskandias nordliga delar IV. Bulletin de la commission Géologique de Finlande, 88, 594 pp., 1930.

Taylor, R. W. and Fleming, A. H.: Characterizing jointed systems by azhimuthal resistivity surveys, Ground Water, 26, 464-474, 1988.

Utting, D. J., Ward, B. C., and Little, E. C.: Genesis of hummocks in glaciofluvial corridors near the Keewatin Ice Divide, Canada, Boreas, 38, 471-481, 2009.

Vorren, T. and Plassen, L.: Deglaciation and palaeoclimate of the Andflord-Vågsfjord area, North Norway, Boreas, 31, 97-125, 2002.

West, M. E., Larsen, C. F., Truffer, M., O’Neel, S., and LeBlanc, L.: Glacier microseismicity, Geology, 38, 319-322, 2010.

Wetterich, S., Grosse, G., Schirrmeister, L., Andreev, A. A., Bobrov, A. A., Kienast, F., Bigelow, N. H., and Edwards, M. E.: Late Quaternary environmental and landscape dynamics revealed by a pingo sequence on the northern Seward Peninsula, Alaska, Quaternary Sci. Rev., 39, 26-44, 2012.

Wu, P., Johnston, P., and Lambeck, K.: Postglacial rebound and fault instability in Fennoscandia, Geophys. J. Int., 139, 657-670, 1999. 